\title{
Preparation of Glutaraldehyde-Treated Red Blood Cells Expressing Weak ABO and RhD Antigens for Use in Tube Methods
}

\author{
Young Ae Lim \\ Department of Laboratory Medicine, Ajou University School of Medicine, Suwon, Korea
}

\section{Corresponding author:}

Young Ae Lim

Department of Laboratory Medicine, Ajou University School of Medicine, 206 World cup-ro, Yeongtong-gu, Suwon 16499, Korea

Tel +82-31-219-5786

Fax +82-31-219-5778

E-mail limyoung@ajou.ac.kr

Received: December 23, 2019

Revised: January 29, 2020

Accepted: February 3, 2020
This is an Open Access article distributed under the terms of the Creative Commons Attribution Non-Commercial License (http://creativecommons.org/licenses/ by-nc/4.0) which permits unrestricted non-commercial use, distribution, and reproduction in any medium, provided the original work is properly cited.
Background: Since there is a paucity of red blood cells (RBCs) with a weak expression of $A, B$, or $D$ antigens, they cannot be used as routine Blood Bank quality control materials. This study aimed to prepare glutaraldehyde-treated RBCs to be weakened $A B O$ and $R h D$ antigen expressions for blood typing.

Methods: RBCs from $A_{1} B$ RhD positive blood group donors were treated with $0.5 \%, 0.375 \%, 0.3125 \%, 0.25 \%$, and $0.125 \%$ concentrations of glutaraldehyde. The treated RBCs were then used for $\mathrm{ABO}$ and RhD blood typing using the tube technique. Differences in agglutination reaction strength and potassium concentrations were compared using treated RBCs stored days for $0,1,4$, and 7 days at $2^{\circ} \mathrm{C}-8^{\circ} \mathrm{C}$.

Results: With an increase in the glutaraldehyde concentrations, the strength of agglutination reaction against anti-A, anti- $B$, anti- $D$, and anti- $A_{1}$ reagents reduced. Most tests showed $2+$ strength with $0.25 \%$ glutaraldehyde treated RBCs. Hemolysis increased with increasing storage time; however, there were no significant differences in strengths until the 7 th day of storage.

Conclusions: The preparation of $0.25 \%$ glutaraldehyde-treated RBCs is simple, and it can be used as a cheap ABO subtype or $D$ variant quality control material. The use of these treated red cells may improve the accuracy of blood typing in Blood Banks.

(Lab Med Qual Assur 2020;42:84-90)

Key Words Erythrocytes, Quality control, Blood group, Glutaraldehyde
서론

$\mathrm{ABO}$ 및 $\mathrm{D}$ 혈액형검사는 환자의 이식의 성공 여부나 환자의 생 명과도 직결되므로 검사의 정확성을 요구하는 매우 중요한 검사이 다. 특히 약하게 표현되는 헌혈자의 $\mathrm{ABO}$ 아형들을 O형으로 간주 하거나 환자의 D 변이형을 정상 D 양성으로 잘못 판정할 경우 수 혈 시 환자에게 항체를 유발하거나 용혈수혈 부작용을 초래할 가 능성이 있다[1-3].

대한임상정도관리협회 수혈의학프로그램에서는 2016년부터 특수항원검사프로그램을 통하여 연 2회 $\mathrm{ABO}$ 아형과 약D검사를
포함하고 있으며, 국내의 많은 종합병원들이 참여하고 있다. 그러 나 2016년부터 2018년도 ABO 아형 혈액형검사의 정답률은 회 차에 따라 각각 참여기관의 $80.7 \%-96.0 \%$, 약D검사 결과를 출제 의도대로 D 변이형을 보고한 기관은 $34.8 \%-80.9 \%$ 로 다른 수혈 의학프로그램 검사종목에 비하여 매우 낮은 정답률을 보였다[46]. 특히 2017년에 발송된 약D검사 검체들은 모두 D 혈액형검사 에서도 정상 D 양성에 비하여 약한 응집을 보였던 D 변이형 검체 였음에도 불구하고 이를 D 양성으로 보고한 기관들도 $47.6 \%$ 와 $21.3 \%$ 에 달하였으며, 2018년 2차에 발송된 D 항원이 약하게 표 현된 D 변이형 검체를 D 음성으로 보고한 기관들도 $63.8 \%$ 나 되 
었다. 이러한 자료들은 모든 검사실에서 $\mathrm{ABO}$ 와 $\mathrm{D}$ 혈액형검사 시 내부정도관리물질로 사용하고 있는 $4+$ 응집등급을 보이는 정상 적혈구 이외에도 $\mathrm{ABO}$ 아형이나 $\mathrm{D}$ 변이형에서 보이는 약한 응집 을(예, 2+ 이하) 보이는 적혈구들도 실제 검사실에서 정도관리물 질로 이용될 필요가 있음을 시사한다.

적혈구를 글루타르알데히드(glutaraldehyde)로 처리하는 시 도들은 수혈용 만능공혈혈액 제조[7] 혹은 적혈구 시약의 유효기 간 연장 등의 목적으로 보고되었으며[8], 각 보고마다 제조방법이 다양하였다. 특히 국내에서 글루타르알데히드를 이용하여 만능공 혈혈액 목적의 적혈구제조 가능성에 대한 $\mathrm{ABO}$ 혈액형과 $\mathrm{D}$ 혈액 형 항원 변형에 대한 보고가 있었기는 하나, 이는 만능공혈혈액 목 적의 항원 변형의 실험실 연구로만 적용되었고, 내부 및 외부정도 관리물질로서의 가능성은 시도해보지 않은 실정이다[7].

이에 본 연구에서는 검사실에서 비교적 쉽게 구할 수 있고 저렴 한 글루타르알데히드를 이용하여 혈액형 항원이 변형된 적혈구를 제조하여 이들의 $\mathrm{ABO}$ 아형 및 $\mathrm{D}$ 변이형 검사의 정도관리물질로 서 사용 가능성을 점검하여 이 검사들을 실시하는 검사실의 질을 향상시키는 데 도움을 주고자 하였다.

\section{재료 및 방법}

\section{1. 연구대상}

아주대학교병원을 내원하여 혈액형검사를 시행하고 남은 폐기 ethylenediaminetetraacetic acid (EDTA) 혈액 중 $1 \mathrm{~mL}$ 이상 잔여량이 남은 검체를 대상으로 하되 응고나 변성된 검체, 용기가 파손된 경우 혹은 기타 예기치 못하게 혈액형검사를 실시하기 어 렵게 된 검체는 제외하였다. 이 연구는 아주대학교병원 임상시험 심사위원회(institutional review board)의 승인을 득한 후 시행 하였다(AJIRB-BMR-KSP-18-162).

\section{2. 연구방법}

기존문헌을 참고하고 기초연구를 통하여 글루타르알데히드의 시약농도별, 배양온도 및 배양시간과 혈구응집반응과의 연관성을 조사하였다[7]. 기초연구결과에서 동일한 글루타르알데히드 농도 하에서 혈구응집강도의 저하는 실온보다 냉장온도에서 그리고 냉 장반응 시 10 분보다 30 분 반응에서 의도했던 반응이 더 잘 나타났 으므로(결과 제시하지 않음) 이 결과를 토대로 최적조건을 다음과 같이 설정하였다.

$25 \%$ 글루타르알데히드(Sigma-Aldrich, St. Louis, MO, USA) 를 멸균식염수로 희석하여 $5 \%$ 로 만든 후 2배씩 희석한 후 희석 한 글루타르알데히드를 혼합하여 원하는 농도로 만들었다. $A_{1} B$ 형 D 양성 EDTA 잔여 검체의 적혈구를 파이펫을 이용하여 시험관 에 $1 \mathrm{~mL}$ 담은 후 pH 7.3-7.4 phosphate buffer solution (PBS; MBL, Nagoya, Japan)으로 3,000 rpm 3분 조건에서 3회 세척 하여 적혈구 농축액을 준비하였다. 세척한 적혈구 농축액에 동량 인 $1 \mathrm{~mL}$ 희석된 글루타르알데히드를 가하여 냉장상태로 30 분간 반응시켰다. 반응 후 혈액형검사를 위하여 PBS로 3,400 rpm 15 초 조건에서 3회 세척한 후 상층액을 완전히 제거하고 PBS를 이 용하여 3\%-5\% 혈구부유액으로 만들었다.

날짜 간 제조변이를 반영하기 위하여 하루에 2 개 검체씩 5 일 에 걸쳐 나누어 적혈구를 제조하였다. 글루타르알데히드의 농도 별 조건을 설정하기 위하여 하루에 2검체씩 5일간에 걸쳐 $0.5 \%$, $0.375 \%, 0.3125 \%, 0.25 \%, 0.125 \%$ 글루타르알데히드로 처리 한 적혈구를 각각 10 개씩 제조하였다. 날짜별 제조변이를 조사하 기 위하여 특정 글루타르알데히드 농도하에 처리된 적혈구를 하루 에 2 개씩 5 일에 걸쳐 10 개를 제조하되, 제조 당일, 보관 1 일, 4 일, 7일 후 검사를 위하여 $3 \%-5 \%$ 혈구부유액을 관찰할 날짜 수만큼 소분하여 마개를 닫아 냉장고에 보관하였다.

혈액형검사 시행 후 농도별 및 날짜별 용혈 변화를 알기 위하여 하루에 혈액형검사를 실시한 2 개의 검체 중 무작위로 한 개씩의

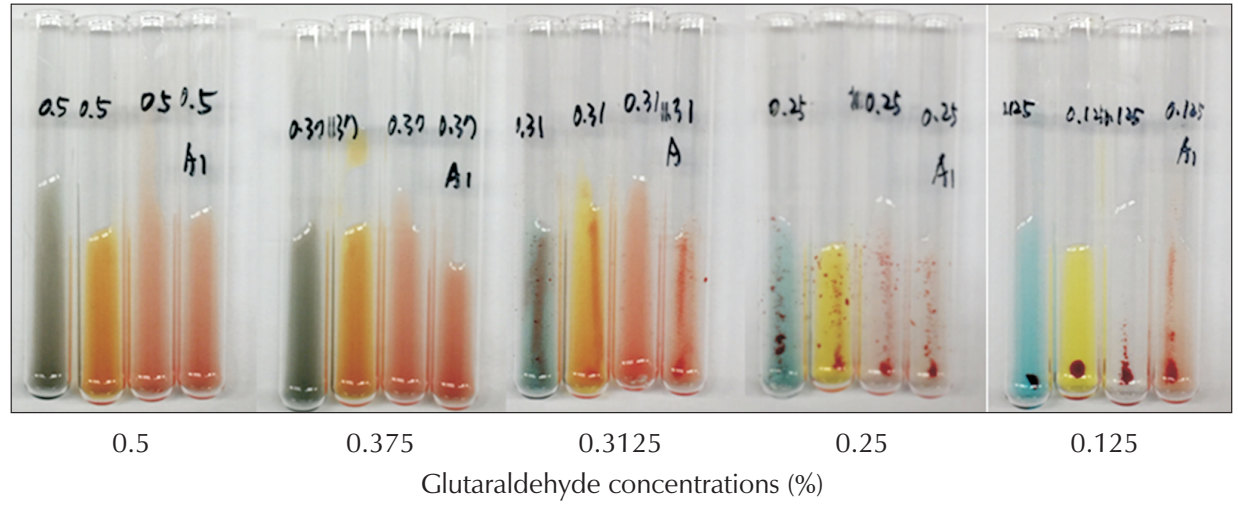

Fig. 1. Tube technique agglutination reaction strengths of $A_{1} B$ $\mathrm{RhD}$ positive red blood cells pretreated with different concentrations of glutaraldehyde against anti-A, - B, -D, and $-A_{1}$ anti-sera: all tubes showed $2+$ reaction strengths against the different anti-sera using $0.25 \%$ glutaraldehyde-treated $A_{1} B$ RhD positive red blood cells. 
검체에서 상층액을 채취하여 추후 $\mathrm{K}$ 검사 측정을 위하여 냉동하였 다.

시험관법의 혈구형검사에 사용된 항혈청은 anti-A (SIHDIA; Shinyang Chemical Co., Seoul, Korea), anti-B (SIHDIA, Shinyang Chemical Co.), anti-D (SIHDIA, Shinyang Chemical Co.), anti-H (Lorne Laboratories Ltd., Berkshire, UK), anti- $\mathrm{A}_{1}$ (Lorne Laboratories Ltd.)로 이 시약들과 냉장보관된 다양한 글루타르알데히드 농도로 처리된 혈구부유액으로 반응시 킨 후 각각 응집강도를 기록하였다. Anti-D 시약에서 음성을 보이
는 경우는 약D검사를 시행하였다. 겔카드법은 DiaClone $\mathrm{ABO} /$ $\mathrm{D}+$ reverse grouping card (Bio-Rad Laboratories Diamed $\mathrm{GmbH}$, Fribourg, Switzerland)를 준비하여 $\mathrm{ABO}$ 와 D 혈구형검 사를 시행하였다.

시험관법의 응집강도(reaction strength)는 1-4의 숫자만 기 록하고 음성은 0 , trace는 0.5 로 기술하였다. 응집강도의 객관성 을 위하여 모든 혈액형검사는 혈액은행 병리사 1 인이 시행하고 판독하였다. 일간 변이를 배제하기 위하여 냉동보관해 둔 상층 액에서 한 번에 potassium (K) 농도를 indirect ion-selective
A
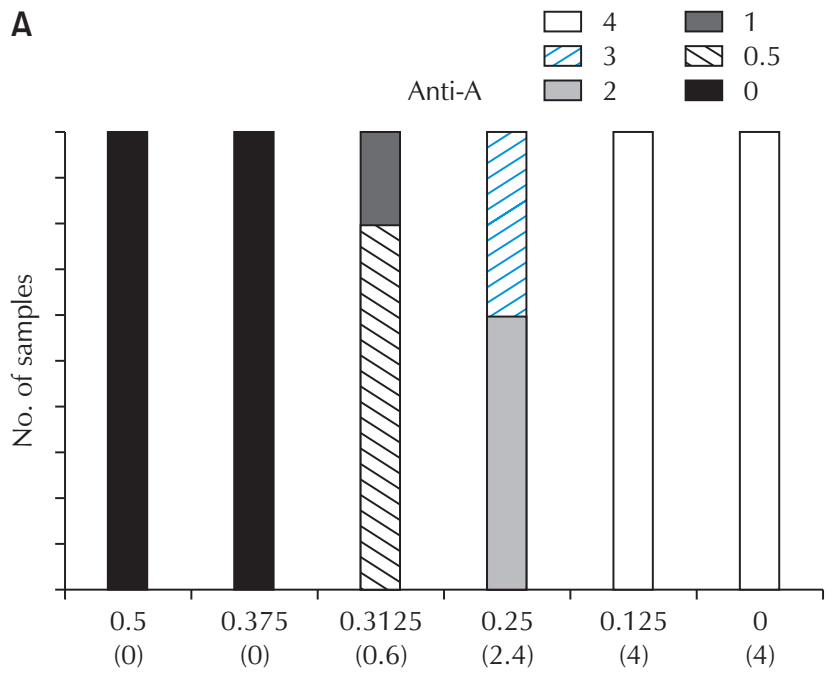

Glutaraldehyde concentration (\%)

C

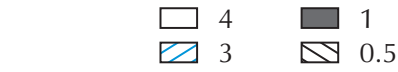
Anti-D $\square 2 \square 0$

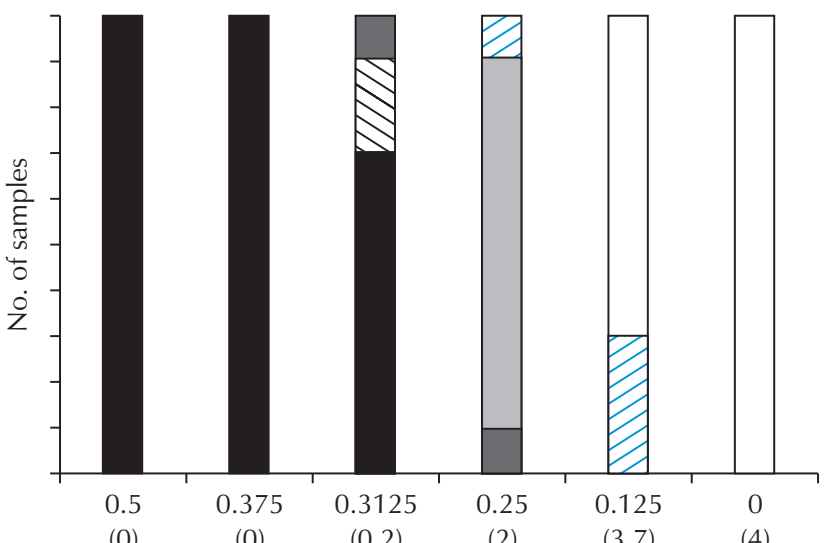

Glutaraldehyde concentration (\%)
B
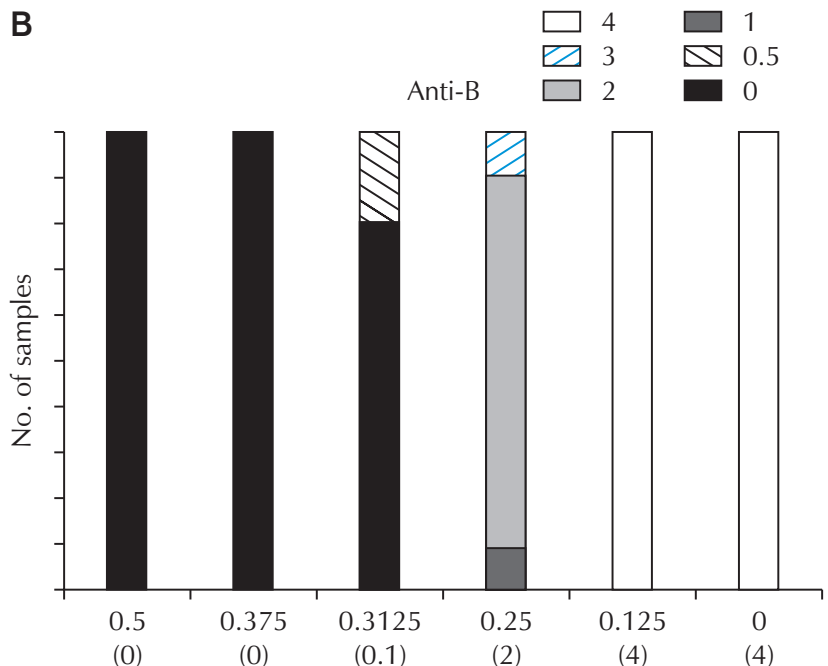

Glutaraldehyde concentration (\%)
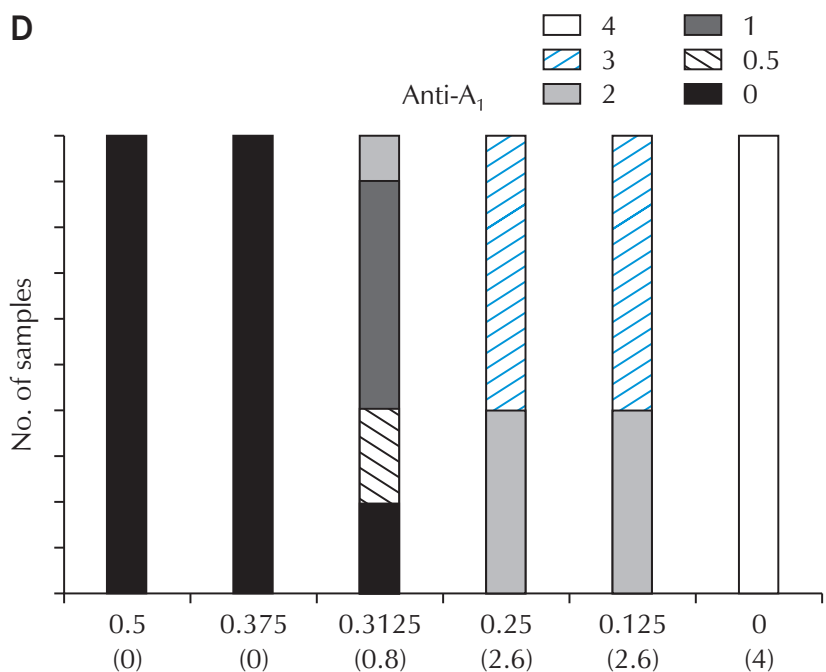

Glutaraldehyde concentration (\%)

Fig. 2. Relationship between glutaraldehyde concentration (\%) and agglutination reaction strength by tube technique using $A_{1} B$ RhD positive red blood cells ( $n=10$ for each concentration). The numbers in parentheses are the average of the agglutination reaction strengths. With an increase in the glutaraldehyde concentrations, there was a decrease in the reaction strengths using anti-A (A), anti-B (B), anti-D (C), and anti- $A_{1}(D)$ reagents. 
electrodes법으로 측정하였다.

\section{3. 통계처리}

자료정리와 통계처리는 Microsoft Excel 2013 (Microsoft Corp., Redmond, WA, USA)과 SPSS ver. 12.0 for Windows (SPSS Inc., Chicago, IL, USA)를 이용하였다. 보관일에 따른 혈 구응집 및 K 농도와 글루타르알데히드 농도별에 따른 K 농도의 변 화는 analysis of variance test를 시행하였고 다중비교는 Tukey honestly significant difference를 사용하였다. $P<0.05$ 를 유의 한 차이가 있는 것으로 간주하였다.
A

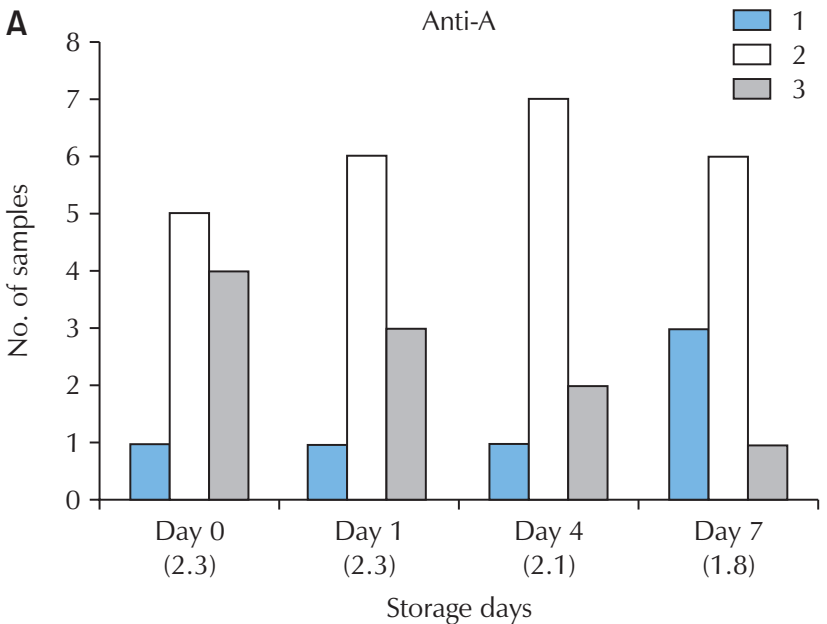

C

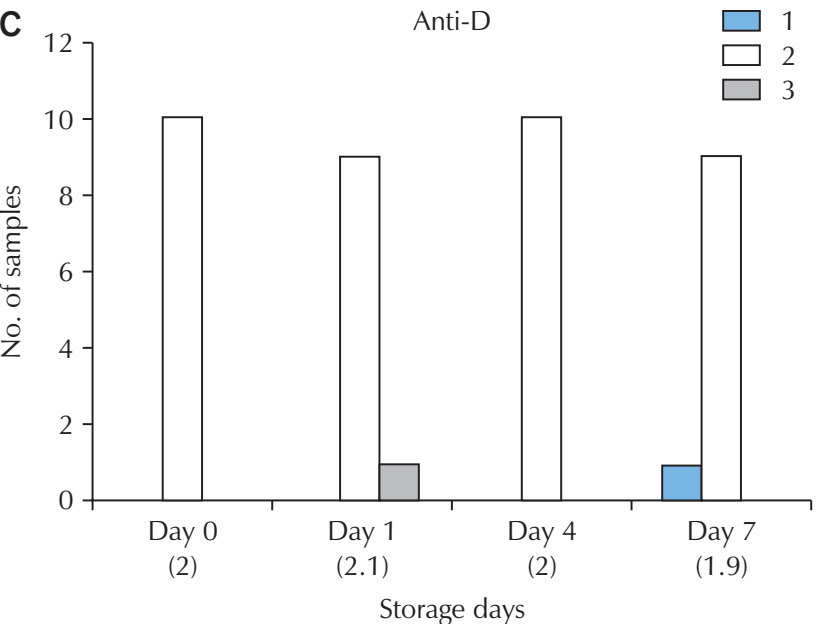

결과

1. 글루타르알데히드 농도별 혈구응집강도

시험관법으로 시행 시 글루타르알데히드 처리 전에는 $A_{1} B$ 형 $D$ 양성 적혈구에 대한 anti-A, anti-B, anti-D의 혈구응집강도는 모 두 4였다. 각 시약마다 글루타르알데히드 농도에 따른 혈구응집강 도 견본은 Fig. 1 과 같고, 각 농도별 10 개 검체들의 결과는 Fig. 2 와 같다.

모든 항혈청 시약에서 $0.5 \%$ 와 $0.375 \%$ 는 혈구응집이 없었으 며, $0.125 \%$ 에서는 응집강도 4 를 보였으나 농도가 감소할 수로 응 집강도가 강해졌다. 글루타르알데히드 $0.25 \%$ 에서 각 시약별 응 집반응을 보이는 검체 개수는 anti-A 시약의 경우 응집강도 2는 6
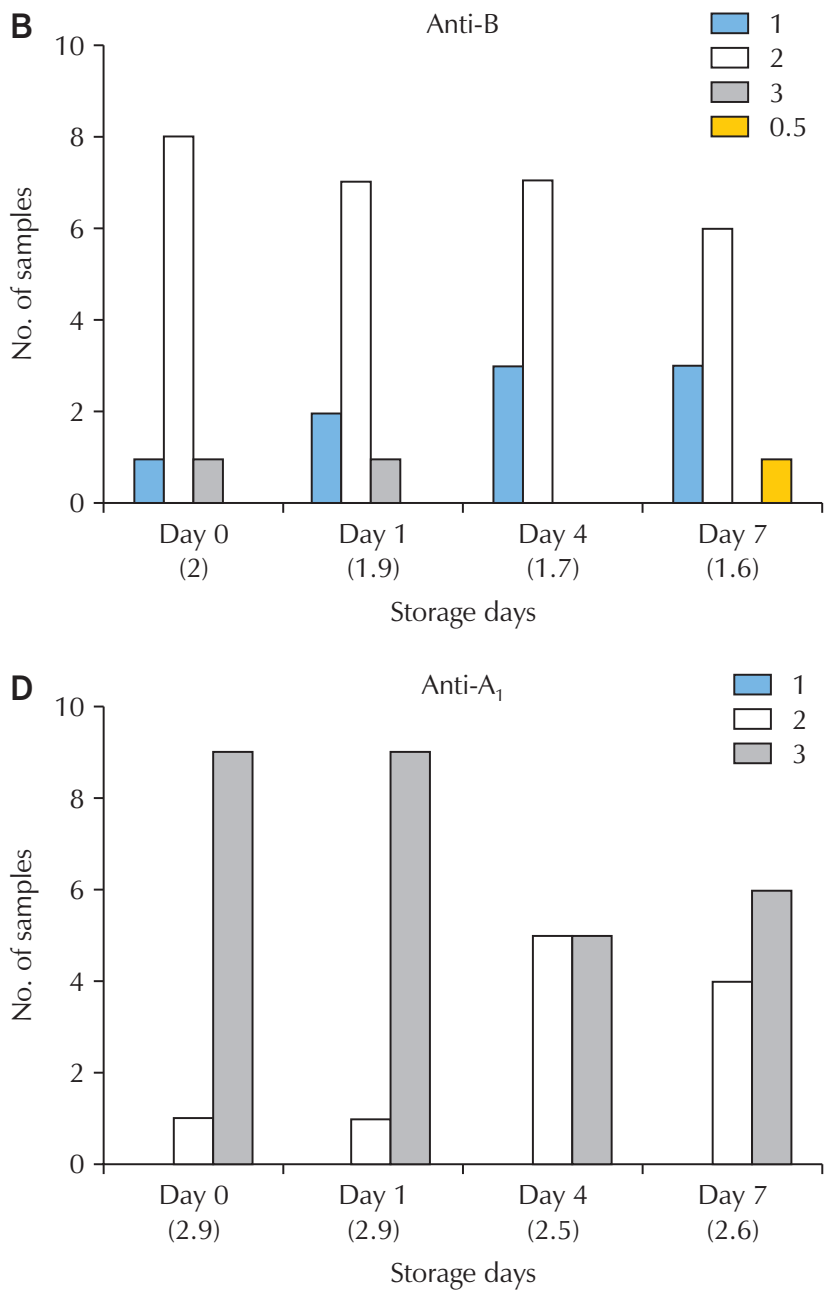

Fig. 3. Number of samples (y-axis) of agglutination reaction strength tests using $0.25 \%$ glutaraldehyde-treated $A_{1} B$ RhD positive red blood cells versus the number of storage days ( $x$-axis, $n=10$ for each day) at $2^{\circ} \mathrm{C}-8^{\circ} \mathrm{C}$. The numbers in parentheses are the average agglutination strengths. There were no significant differences in reaction strengths between storage days for anti-A $(P=0.268)(A)$, anti-B $(P=0.250)(B)$, anti-D ( $P=0.279)(C)$, and anti- $A_{1}(P=0.096)$ (D). 


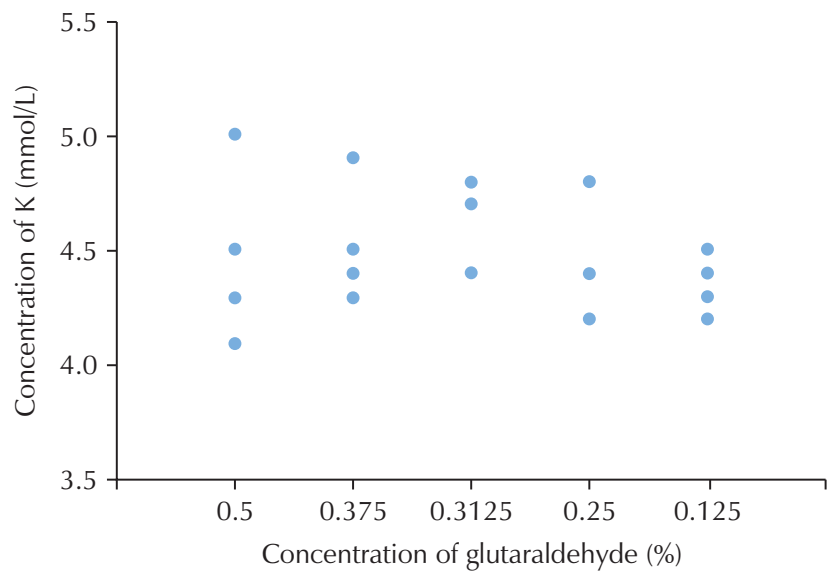

Fig. 4. Relationship between glutaraldehyde concentration (\%) and potassium concentrations ( $n=5$ for each concentration).

개, 응집강도 3은 4개, anti-B와 anti-D 시약의 경우 각각 응집강 도 1 과 3 이 각각 1 개씩으로 나머지 8 개는 응집강도 2 를 보였다. Anti-D 시약에서 음성을 보인 $0.5 \%, 0.375 \%$ 모든 검체와 7 개의 $0.3125 \%$ 에서 실시한 약D검사는 모두 음성이었다. Anti- $\mathrm{A}_{1}$ 시약 의 경우 $0.5 \%$ 와 $0.375 \%$ 에서는 anti-A와 동일하게 응집이 없었 으나 $0.3125 \%$ 이하에서는 anti-A 시약보다 혈구응집반응이 강하 여 1 혹은 0.5 를 보이는 검체도 있었으나, $0.25 \%$ 와 $0.125 \%$ 에서 anti-A 시약과 동일한 혈구응집을 보였다. Anti-H 시약의 경우 처 치 전과 마찬가지로 1 일차 2 개의 검체에서 글루타르알데히드 농 도에 상관없이 혈구응집을 모두 보이지 않아 더 이상의 실험은 진 행하지 않았다. 겔카드로 혈구형검사를 시행하였을 때는 $0.5 \%$ 와 $0.375 \%, 0.25 \%$ 모두 응집강도 4 를 나타내어 농도에 따른 혈구응 집의 변화를 보이지 않아 더 낮은 농도의 글루타르알데히드 처리 적혈구는 제조하지 않았다.

\section{2. $0.25 \%$ 글루타르알데히드 처리 적혈구의 날짜별 혈구응집강도}

시험관법으로 시행 시 글루타르알데히드 농도별 혈구응집강 도 실험에서 응집강도 2 를 보인 $0.25 \%$ 로 처리한 10 개의 검체 에서 보관일, 보관 후 1일, 4일과 7일 동안 각각 anti-A, anti-B, anti-D를 측정한 결과는 Fig. 3과 같다. Anti-A ( $P=0.268)$, anti-B $(P=0.250)$, anti-D $(P=0.279)$, 그리고 anti- $\mathrm{A}_{1}(P=0.096)$ 의 경우 보관일이 증가하면서 혈구응집강도가 감소하는 경향을 보였으나, 모두 보관일에 따른 혈구응집강도의 유의한 차이는 없었다(Fig. 3). 겔카드로 혈구형검사를 시행하였을 때는 $0.25 \%$ 처리 적혈구 에서 제조 당일 모두 응집강도 4 를 나타내어 보관일에 따른 변화 는 관찰하지 않았다.

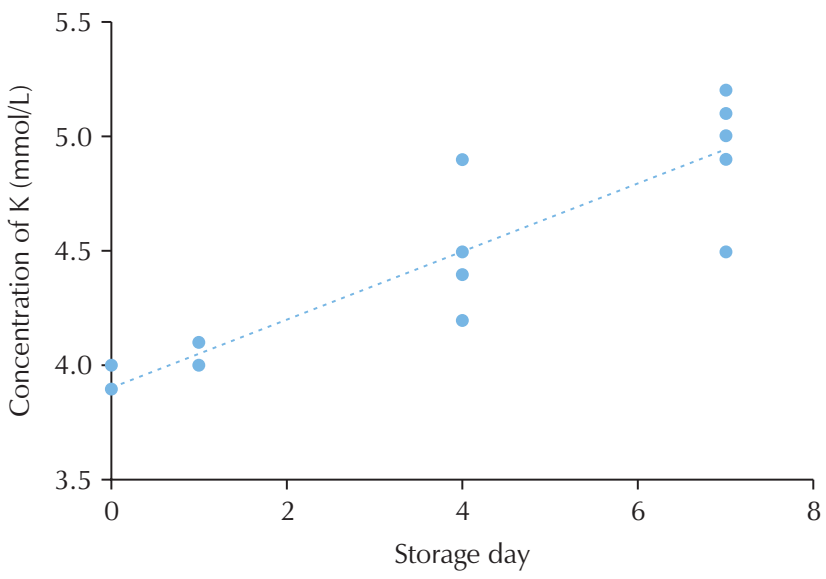

Fig. 5. Comparison of potassium concentrations in $0.25 \%$ glutaraldehyde-treated red blood cells and storage days at $2^{\circ} \mathrm{C}-8^{\circ} \mathrm{C}$ $(P<0.0001, \mathrm{n}=5$ for each day).

\section{3. $K$ 측정결과}

글루타르알데히드 농도별 K 농도의 변화는 유의한 차이가 없었 으나 $(P=0.486)$ (Fig. 4), 보관일에 따른 $\mathrm{K}$ 농도는 유의한 차이를 보였는데 $(P<0.0001)$, 제조일에 비하여 보관일 4일과 $(P=0.001) 7$ 일째 $(P<0.0001)$ 유의하게 증가하였다(Fig. 5).

\section{고찰}

혈구형검사에서 약한 혈구응집을 보이는 $\mathrm{ABO}$ 아형 및 $\mathrm{D}$ 변이 형 적혈구를 검사실에서 직접 확보하는 방법은 5 가지가 있다. 첫 번째, $\mathrm{ABO}$ 아형 및 $\mathrm{D}$ 변이형 헌혈자로부터 얻어진 혈액 중 폐기되 는 혈액을 이용할 수 있겠으나 $\mathrm{ABO}$ 아형의 빈도가 $0.05 \%-1 \%$ 정 도로 낮으며[9,10], D 변이형 또한 매우 드문 혈액형이다. 따라서 국내 검사실들이 이러한 혈액을 직접 구하여 내부정도관리물질로 이용한다는 것은 현실적으로 불가능하겠다.

두 번째, 'function-spacer-lipid (FSL)' 구조물을 이용하여 $\mathrm{ABO}$ 아형 검사용 kodecyte를 제조하는 방법이다. FSL를 이용하 여 정상 항원량에 비하여 다양한 항원량을 지닌 $\mathrm{A}$ 아형 혹은 $\mathrm{B}$ 아 형 kodecytes를 제조하여 내부 및 외부정도관리물질로서 사용할 수 있다[11,12]. 그러나 이러한 kodecytes는 D 혈액형 항원에는 적용할 수 없으며 FSL 시약이 고가라는 단점이 있다.

세 번째, 효소를 이용하여 적혈구막의 $\mathrm{H}$ 항원을 변형하거나 exoglycosidase를 이용하여 혹은 B형 적혈구를 효소전환 O형 만 능적혈구로의 전환을 시도한 보고들이 있다[13,14]. 그러나 이들 또한 D 혈액형 항원에는 적용할 수 없으며 효소가 비싸다는 단점 이 있다.

네 번째, 유전자기법을 이용하여 조혈모세포로부터 원하는 혈 
액형 유전자를 조작하여 혈액형을 발현시키거나 없애는 방법이다 [15]. 그러나 이 방법은 비경제적이며 일반 혈액은행 검사실에서 손쉽게 얻을 수 없다는 단점들이 있다.

마지막으로, 화학약품을 이용하여 혈액형 항원이 화학적으로 변형된 적혈구를 제조하는 방법이다. Methoxy polyethylene glycol (mPEG), 글루타르알데히드 등을 사용하여 적혈구 막을 변 형시켜 혈액형 항원을 인위적으로 위장함으로써 혈액형들의 노출 을 방지할 수 있으므로 만능공혈혈액의 목적으로 이를 제조하려는 시도들이 있었다 $[7,16,17]$.

$\mathrm{mPEG}$ 를 이용한 만능공혈혈액 제조에 대한 시도들이 많이 보 고되었으나 정도관리물질로서의 시도는 없었다. 그러나 $\mathrm{mPEG}$ 는 글루타르알데히드에 비하여 검사실에서 쉽게 얻을 수 없으며 적 혈구 단백질과 반응하기 위해서는 cyanuric chloride 등으로 활 성화시켜야 하는 전처치과정이 필요하므로 복잡하고 이미 활성화 시킨 cyanuric chloride-activated mPEG는 고가라는 단점이 있 다. 반면 글루타르알데히드는 조직의 고정용액으로 검사실에서 비 교적 쉽게 얻을 수 있으며 경제적이라는 장점이 있다.

본 연구에서는 시중에 판매되는 $25 \%$ 글루타르알데히드를 이용 하여 시험관법 혈구형검사에서 $\mathrm{ABO}$ 아형 및 D 변이형 검체로서 흔히 관찰되는 2 혈구응집강도를 보이는 $0.25 \%$ 글루타르알데히 드 농도를 찾아내었으며 $[18,19]$, 이에 대한 처리 제조조건도 설정 하였다는 데 의의가 있겠다. 각 클론마다, 제조회사마다 혹은 lot 번호마다 항혈청 역가의 차이는 있겠지만, 이는 $0.25 \%$ 글루타르 알데히드 농도를 약간 조정한다면 2 정도의 혈구응집강도를 얻을 수 있으며, 또한 검사실에서 필요한 혈구응집강도에 맞게 글루타 르알데히드 농도를 조절하여 검사실에 맞게 사용할 수 있다는 장 점이 있다. 따라서 본 연구에서 제조된 글루타르알데히드 처리 적 혈구는 $\operatorname{Lim}$ 등[7]의 보고에서 만능공혈자 혈액목적으로 2\%-3\% 글루타르알데히드를 이용하여 anti-A, anti-B, anti-D 시약의 항 혈청 역가가 저하되는 정도를 확인하였으나, 적혈구 $\mathrm{ABO}$ 및 $\mathrm{D}$ 항 원의 혈구응집정도를 확인하지 않았던 적혈구에 비하여 $\mathrm{ABO}$ 아 형 및 D 변이형 검체에 더 특화된 검체라 할 수 있다.

비록 7일동안 보관 시 용혈이 점점 증가하기는 하나, 이 정도의
용혈이 혈구응집의 강도에는 영향을 미치지 않았으므로 제조 후 최소한 일주일은 냉장보관이 가능하므로 검사실에서 자주 제조하 여야 하는 번거로움은 없어도 될 것으로 여겨졌다.

겔카드법의 혈구형검사에서는 글루타르알데히드 농도에 상관 없이 항원성이 낮아지지 않았는데, 이는 아마도 글루타르알데히드 로 처리된 적혈구는 분자량이 크기 때문인 것으로 여겨졌다. 처리 된 적혈구는 마치 응집된 혈구처럼 겔카드의 상층부에 그대로 존 재하여 원리상 4 로 판독되기 때문인 것으로, 글루타르알데히드로 처리된 적혈구가 겔카드법에서는 유용하지 않음을 확인할 수 있었 다.

글루타르알데히드로 처리된 적혈구의 또 다른 제한점으로는 O 형으로부터 제조된 kodecytes에 비하여 anti-H 시약과 anti- $\mathrm{A}_{1}$ 시약과의 반응에서 전형적인 $\mathrm{ABO}$ 아형의 성상을 보이지 않는다 는 점이다[11]. $\mathrm{ABO}$ 아형인 경우 anti-H 시약에는 양성 반응, $\mathrm{A}$ 아형인 경우 anti- $A_{1}$ 시약과는 음성 반응을 보여야 하나, 적혈구의 모든 항원이 글루타르알데히드로 가려지기 때문에 $\mathrm{H}$ 항원도 가려 져서 anti-H 시약과의 반응에서 항상 음성을 보인다는 점이다. 또 한 anti- $\mathrm{A}_{1}$ 시약과의 반응에서는 $0.3125 \%$ 에서 일부 양성을 보이 기도 하나 이 농도에서는 $\mathrm{A}$ 형 혹은 $\mathrm{B}$ 형에 대한 다른 항혈청과의 반응이 매우 약해지기 때문이다. $\mathrm{ABO}$ 혈액형이 trace 정도로 약 해지더라도 이를 그대로 정도관리물질로 이용하거나 혹은 anti- $\mathrm{A}_{1}$ 시약 정도관리를 위한 별도 농도의 글루타르알데히드 처리 적혈구 를 제조하여 이용할 수 있겠다.

따라서 본 연구에서 제시한 $0.25 \%$ 글루타르알데히드 처리 적 혈구는 경제적이면서 간단하게 $\mathrm{ABO}$ 아형이나 $\mathrm{D}$ 변이형의 내부정 도관리물질로서 사용이 가능하여 궁극적으로 검사실의 혈액형 아 형검사의 정확성을 기하는 데 도움이 될 것으로 생각된다.

\section{감사의 글}

이 논문은 대한임상검사정도관리협회 2018년 학술연구비 지원 에 의해 이루어진 것이다(2018-1). 실험을 시행해 주신 조현수 선 생님께 감사드린다.

\section{REFERENCES}

1. Oh HB, Han KS, Kim BK, Han BY, Cho HI. A case of Bm. Korean J Blood Transfus 1993;4:97-101.

2. Whang DH, Shin BM, Lee HS, Hur M, Han BY, Han KS. Unusual phenotype expression in a cis-AB trait: cis-AB child from a group A father and a group 0 mother. Korean J Blood Transfus 2000;11:169-75.

3. Cho D, Jeon MJ, Song JW, Lee JS, Choi HW, Kwon SY, et al. Serologic variability of the A(var) (784G>A) and its property of different expression depending on co-inherited ABO allele. Korean J Blood Transfus 2006;17:61-70.

4. Lim YA, Cho HS. Annual report on the external quality assessment scheme for immunohematology testing in Korea 
(2016). J Lab Med Qual Assur 2017;39:107-16.

5. Lim YA, Cho HS. Annual report on the external quality assessment scheme for transfusion medicine in Korea (2017). J Lab Med Qual Assur 2018;40:9-20.

6. Lim YA, Cho HS. Annual report of the Korean Association of External Quality Assessment Service on transfusion medicine (2018). J Lab Med Qual Assur 2019;41:65-74.

7. Lim CS, Kim IT, Ma KR, Kim YK, Lee KN, Byun SM. Chemical modification of RBC surface antigen with glutaraldehyde crosslinking. Korean J Blood Transfus 1998;9:45-9.

8. Yu Y, Sun X, Guan X, Zhang X, Ma C, Chen L, et al. Effects of hydroformylation treatment on the storage time and blood group antigen expressions of reagent red blood cells. Transfus Apher Sci 2014;50:462-6.

9. Cho D, Kim SH, Jeon MJ, Choi KL, Kee SJ, Shin MG, et al. The serological and genetic basis of the cis-AB blood group in Korea. Vox Sang 2004;87:41-3.

10. Lee JY, Oh DJ, Park YM. The frequency and distribution of the ABO subgroups in Korean blood donors. Korean J Blood Transfus 2010;21:223-9.

11. Lim YA, Kang SJ. Evaluation of kodecytes using function-spacer-lipid constructs as a survey material for external proficiency testing for ABO subgrouping. J Clin Lab Anal 2017;31:e22116.

12. Henry SM. Modification of red blood cells for laboratory quality control use. Curr Opin Hematol 2009;16:467-72.

13. Henry SM, Gilliver LG. Preparation of red blood cells with a modified level of blood group antigen expression and their use in the quality control of blood typing reagents: international patent application no. PCT/NZ2004/000030 (publ. no. WO 2004/072306). Geneva: World Intellectual Property Organization; 2004.

14. Goldstein J, Siviglia G, Hurst R, Lenny L, Reich L. Group B erythrocytes enzymatically converted to group O survive normally in A, B, and O individuals. Science 1982;215:168-70.

15. Bagnis C, Chapel S, Chiaroni J, Bailly P. A genetic strategy to control expression of human blood group antigens in red blood cells generated in vitro. Transfusion 2009;49:967-76.

16. Jeong ST, Byun SM. Decreased agglutinability of methoxy-polyethylene glycol attached red blood cells: significance as a blood substitute. Artif Cells Blood Substit Immobil Biotechnol 1996;24:503-11.

17. Bae JS, Hwang MW, Kim IT, Lim CS, Ma KR, Kim YK, et al. Chemical modification of RBC surface antigen with methoxy polyethylene glycol. Korean J Clin Pathol 1999;19:723-8.

18. Lim YA, Cho HS, Choi YS, Jang CH, Lee MN, Kwon JR, et al. Report on external proficiency testing for the ABO and D blood group typing tests in blood centers (2015). Korean J Blood Transfus 2016;27:68-78.

19. Nacharaju P, Boctor FN, Manjula BN, Acharya SA. Surface decoration of red blood cells with maleimidophenylpolyethylene glycol facilitated by thiolation with iminothiolane: an approach to mask $A, B$, and $D$ antigens to generate universal red blood cells. Transfusion 2005;45:374-83. 